\title{
Customer Relationship Management (CRM) Implementation Perception and Barriers for Zakat Institution: Case Study Approach
}

\author{
Azhar Hamid \\ Faculty of Computer \\ Science and Information \\ Technology, \\ Universiti Selangor, \\ Malaysia
}

\author{
Wan Azlan Wan \\ Hassan Wan Harun \\ Faculty of Computer \\ Science and Information \\ Technology, \\ Universiti Selangor, \\ Malaysia
}

\author{
Muhammad Hashim \\ Faculty of Computer \\ Science and Information \\ Technology, \\ Universiti Selangor, \\ Malaysia
}

\author{
Mohamad Syakiran \\ Muhammad \\ Faculty of Computer \\ Science and Information \\ Technology, \\ Universiti Selangor, Malaysia
}

\author{
Mohd Fahmi Mohamad \\ Amran \\ Computer Science Department, \\ Faculty of Science and \\ Defense Technology, \\ National Defence University of \\ Malaysia, \\ Kuala Lumpur, Malaysia
}

\author{
Suziyanti Marjudi \\ Faculty of Computer \\ Science and Information \\ Technology, \\ Universiti Selangor, Malaysia
}

\begin{abstract}
Zakat is one of the demands that must be fulfilled by the Muslims who have the ability to contribute in terms of property or money to be distributed to the poor and the needy as well as other beneficiaries based on certain Qur'an verses that clearly stated the compulsory of Zakat obligations. Therefore, a systematic and efficient mechanism is necessary for the collection and distribution of Zakat. It is important to identify the perception and the barriers for the implementation of Zakat CRM system. The method for this research is using a case study which comprises interview session with several groups, observation of work processes and report analysis. This research is towards establishment of implementation framework for Zakat CRM system.
\end{abstract}

\section{General Terms}

Customer Relationship Management

\section{Keywords}

Zakat CRM system, perceptions and barriers

\section{INTRODUCTION}

Zakat payer and receiver or customers of Zakat institution played a very important role in the Zakat process of collection and distribution. Zakat refers to spending a fixed portion of one's wealth to the poor and needy in the community (8). Zakat is one of the main pillars in Islam and it is obligatory for every Muslim to perform Zakat. In terms of language, the word refers to an act of charity to cleanse or purify something dirty, while theologically, it refers to pure spiritual life through acts of charity. Zakat literally means to develop and improve (1)(12). Legally, Zakat means the transfer of ownership of specific assets to certain individuals under certain conditions (1).

The majority Zakat payers in Malaysia are not satisfied with the way the institution of Zakat distribute Zakat. They argue the distribution process is vague and information on the distribution of Zakat is not clear. Another problem that has been recognized of Zakat institutions in Malaysia is a shortage of staff and experts in the institutions of Zakat compared with many tasks under their responsibility. It is caused by several problems, including the lack of management expertise, lack of commitment, lack of information and other aspects of the law (10).

The issue with the distribution of Zakat is very important because it may cause dissatisfaction among the people who pay the Zakat that in the future might bring them to pay Zakat directly to recipients, bypassing the institutions of Zakat causing a lot of problems later. Issues concerning leakage Zakat collection and distribution to the possible recipients may happen if the Zakat payers pay Zakat directly to the recipients, especially to the people who need help and poor (13).

In addition, CRM is one of the hottest topics in information technology and the integration of business and technology process for customer satisfaction and to meet customer needs (2). CRM is, essentially, a business strategy that aims to help companies maximize customer benefit and integrated customer process (14). CRM system is also considered as a " front office " system because they are concerned with the organization's relationship with other sources of income (9). CRM is vital to any organization where companies want to know the relationship between customers and their organizations. In the years before, the CRM has been a part of success for any organization (3). Therefore, CRM system implementation for Zakat institution is very significant to ensure the smooth process of collection and distribution.

With the issues of Zakat collection and distribution, the following question is addressed to identify the perceptions and barriers towards the implementation of CRM Zakat system: 
1. What are the perceptions on the current process and practices of the collection and distribution system? This question involves perceptions by the Board of Directors, management and administrative level, and the customer.

2. What are the barriers towards the implementation of CRM Zakat system?

3. Is proper CRM system is required to ensure collection and distribution are done systematically and efficiently?

The answers to the addresses questions will fulfill the specific objectives of this research which are as follows:

1. To investigate the perceptions of administrative and Zakat payer.

2. To examine the barriers to the implementation of CRM Zakat system.

The objectives of this research imply that this research is significant and the contribution is great to the people and country. This is because Zakat wealth is distributed to the people who are in need and poor. In Surah At-Taubah Allah (s.w.t.) said: "Alms are for the poor and the needy, and those employed to administer the (funds); for those whose hearts have been (recently) reconciled (to Truth); for those In bondage and In debt; In the cause of Allah and for the wayfarer: (thus is it) ordained by Allah, and Allah is full of knowledge and wisdom." (Al-Quran 9:60)

To implement Zakat, the Muslim community is obligated to establish the institution of Zakat in order to collect Zakat from rich Muslims in the society and distribute it to the beneficiaries (asnaf) especially the poor and needy (4). In conjunction with that, this study is limited to Malaysian Zakat Institution. This study aims to examine the perception and barriers to the Zakat CRM system towards the establishment of implementation framework for Zakat CRM system. Data for this research is from using a case study which comprises interview session with several groups, observation of work processes and report analysis.

\section{LITERATURE REVIEW}

Zakat has been practiced since the beginning of the Muslim community in Mecca with the main objective is to help the poor and the needy (12). Consistent with the brotherhood concept in Islam, Muslims were strongly encouraged to look after the poor in their community. As stated in Surah AlMuddahthir, verse 38-45, one of the reasons those people are sent to Hell is because of the failure to feed the poor and the needy. Although Zakat has been practiced earlier in Mecca, it was only made compulsory after hijrah to Medina. In general, there are two types of Zakat, i) Zakat al-fitr or Zakat on oneself, and ii) Zakat almal or Zakat on wealth. Zakat al-fitr was made compulsory for all Muslims in $2 \mathrm{AH}$ (after Hijra). It is a small amount that all Muslims are obliged to pay during the fasting month (Ramadhan). On the other hand, Muslims also have been required to pay Zakat al-mal since $9 \mathrm{AH}$ and it is payable at any time of the year if a person's annual income (haul) exceed the exemption limit (nisab) (7).

In Malaysia, the Zakat management is different between states where only Selangor, Pulau Pinang and Serawak have privatized their Zakat management process. Meanwhile, Kuala Lumpur Federal Territory, Negeri Sembilan, Melaka and Pahang are the states that only privatized the Zakat collection while State Islamic Religious Council (SIRC) will handle the distribution process. The other states namely Kedah, Perlis, Sabah, Kelantan, Perak, Terengganu, Johor,
Putrajaya and Labuan Federal Territory have not privatized either Zakat collection or distribution where SIRC is the only institution manages the Zakat totally (7) (15). Privatization means the process of transfer of government services or assets to the private sector to improve the quality and performance significantly (10).

The use and implementation of the CRM system has increased over the last decade, along with issues of academic research related to the issues of the implementation process, which has somehow have been identified and controlled (6). CRM system implementation process refers to all functions, technical and organizations involved in activities preparation and introduction of the system into company, either install the software throughout the company, or in strategic areas (5). Critical Success Factors (CSF) was related issues that need to be addressed and needs to be tackled in the implementation process to satisfy the process. These factors must be kept present and handled properly during any CRM. According to the project implementation (11), the main CSF from the implementation of CRM is shown in Table 1as follows:

Table 1: Critical Success Facto (CSF) for Customer Relationship Management (CRM)

\begin{tabular}{|l|l|}
\hline \multicolumn{2}{|c|}{ CSF for CRM } \\
\hline -Top management support & -Technological readiness \\
-Communication of CRM & -Culture change/customer \\
strategy & orientation \\
-Knowledge management & -Process change capability \\
capabilities & -Systems integration \\
-Willingness to share data & capability \\
-Willingness to change & \\
processes & \\
\hline
\end{tabular}

Literature review conducted to identify some aspects of Zakat system that has been done by previous researchers. It is fundamental to know the current situation and development of the organization and operation of Zakat in Malaysia. This study will provide important indications regarding the issues faced and the steps that need to be done to meet the challenges to the implementation of the collection and distribution more efficient.

\section{RESEARCH METHODOLOGY}

Interview conducted by researchers covering the entire level of management and administration of the Zakat institution. Studies carried out by dividing into small groups involving every department and unit in the institution. The review process is initiated by interviewing 42 participants which are consists of the Board of Directors, top management Zakat institution, branch manager, executive and administration staff. The interview focused to understand the organization's vision and mission, policies relating to the distribution and collection, as well as improvements to achieve the objectives of the Zakat institution. Interviews are then broken down into three small groups and it was done in parallel with the departments and selected branches. Observations and simulations were conducted in each department to understand the processes and applications that are currently used. In general, the research framework can be described as the diagram in figure 1 below: 

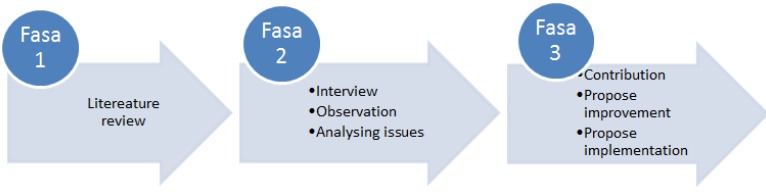

Figure 1: Research framework

Table 2: Problems and solutions of Zakat collections and distributions.

\begin{tabular}{|c|c|c|c|}
\hline No & Problem Statement & Solution & Category \\
\hline 1 & Limited method of collection. & $\begin{array}{l}\text { Various methods of collection: } \\
\text { FPX (EPS), SMS, Phone, Credit cards } \\
\text { and Mobile apps. }\end{array}$ & Collection \\
\hline 2 & Less close relationship with customers. & $\begin{array}{l}\text { i. Intensive Customer Relationship } \\
\text { Management System. } \\
\text { ii. The concept of 'personalization' - i.e. } \\
\text { award payments via SMS }\end{array}$ & $\begin{array}{l}\text { Collection and } \\
\text { Distribution }\end{array}$ \\
\hline 3 & $\begin{array}{l}\text { There is no standard process for payroll deductions } \\
\text { for employer. }\end{array}$ & $\begin{array}{l}\text { Providing on-line system that stores } \\
\text { information Zakat company }\end{array}$ & Collection \\
\hline 4 & $\begin{array}{l}\text { No association with SSM for the performance of } \\
\text { the company of the Islamic trader (Zakat } \\
\text { business). }\end{array}$ & $\begin{array}{l}\text { 'Electronic Data Interchange' between } \\
\text { Zakat PP and SSM. }\end{array}$ & Collection \\
\hline 5 & $\begin{array}{l}\text { E-Zakat, Telebanking and SMS could not be } \\
\text { implemented due to the fatwa issued by the mufti } \\
\text { of the state (Feedback from the Board of } \\
\text { Directors). }\end{array}$ & Refer to the latest issue fatwa (policy). & Collection \\
\hline 6 & $\begin{array}{l}\text { Customers cannot print their own Zakat payment } \\
\text { statement (issue of data security problems). }\end{array}$ & Provide systems with high security & Collection \\
\hline 7 & Problems of repeated questions by customers. & $\begin{array}{ll}\text { i. } & \begin{array}{l}\text { Provides answers to frequently asked } \\
\text { questions (FAQ). }\end{array} \\
\text { ii. } & \begin{array}{l}\text { Knowledge Management System } \\
\text { (KMS) }\end{array}\end{array}$ & Collection \\
\hline 8 & $\begin{array}{l}\text { No application diversity for a customer. Customer } \\
\text { uses a manual form due to a serial number issue. }\end{array}$ & $\begin{array}{l}\text { Facilitate the application form: } \\
\text { i. For existing applicant, confirm the } \\
\text { applicant's identity card and through } \\
\text { supporting document. } \\
\text { ii. Upload form via the website. } \\
\text { iii. Electronic online form. } \\
\text { iv. The system is integrated with the } \\
\text { form (Collection and Distribution) }\end{array}$ & Distribution \\
\hline 9 & $\begin{array}{l}\text { Zakat aid form has a serial number that can be } \\
\text { approved only by the General Manager. }\end{array}$ & $\begin{array}{l}\text { i. The full results of the inquiry assisted } \\
\text { by the system. } \\
\text { ii. Approval status of the system will be } \\
\text { given to the General Manager. } \\
\text { iii. Electronic approval process by using } \\
\text { the information system. }\end{array}$ & Distribution \\
\hline 10 & $\begin{array}{l}\text { There is no centralized information on the process } \\
\text { causing overlapping distribution of Zakat. }\end{array}$ & $\begin{array}{l}\text { Application through the system is verified } \\
\text { through identity cards. }\end{array}$ & Distribution \\
\hline 11 & $\begin{array}{l}\text { No wedding information but only information on } \\
\text { dependent. }\end{array}$ & $\begin{array}{l}\text { Applicants must have adequate } \\
\text { qualifications and knowledge of the } \\
\text { requirements Zakat distribution. }\end{array}$ & Distribution \\
\hline 12 & $\begin{array}{l}\text { Website - managed by a third party and no } \\
\text { integration with Zakat information system. }\end{array}$ & $\begin{array}{l}\text { All ICT system overseen by the } \\
\text { Department of IT (technical) and } \\
\text { Customer Relations Office (information } \\
\text { content). }\end{array}$ & ICT \\
\hline 13 & $\begin{array}{l}\text { No system integration between Zakat Information } \\
\text { System (SMZ) with financial systems, human } \\
\text { resources and procurement. }\end{array}$ & $\begin{array}{l}\text { All systems are monitored by the ICT and } \\
\text { SMZ integrated with the system - other } \\
\text { systems. }\end{array}$ & ICT \\
\hline 14 & $\begin{array}{l}\text { Marketing more effective and attractive should be } \\
\text { implemented effectively and systematically. }\end{array}$ & $\begin{array}{ll}\text { i. } & \text { Augmented reality marketing } \\
\text { techniques marketing placed in the } \\
\text { restaurants, stores, etc. } \\
\text { ii. Optimize use of the latest social } \\
\text { media optimization (Sentiment } \\
\text { analysis, RapidMiner). }\end{array}$ & $\begin{array}{l}\text { Collection and } \\
\text { Distribution }\end{array}$ \\
\hline
\end{tabular}

\section{RESULT}

The findings from the interviews, observations and document analysis, issues and problems, and solutions that have been identified are categorizes into three parts which are collection, distribution and ICT. The results of the findings are shown in Table 2 as follows: 


\section{DISCUSSIONS AND CONCLUSION}

Based on the results of the study and the analysis conducted, it can be concluded that perceptions and barriers to the implementation of Zakat CRM system are as follows (Table 3 and Table 4):

Table 3: Perceptions of administrative and Zakat payer

\begin{tabular}{|l|l|l|}
\hline \multicolumn{1}{|c|}{$\begin{array}{c}\text { Board of } \\
\text { directors } \\
\text { perception }\end{array}$} & \multicolumn{1}{|c|}{$\begin{array}{c}\text { Management } \\
\text { perception }\end{array}$} & \multicolumn{1}{c|}{$\begin{array}{c}\text { Customer } \\
\text { Perception }\end{array}$} \\
\hline $\begin{array}{l}\text { The need to } \\
\text { improvise the } \\
\text { current zakat } \\
\text { system to the state } \\
\text { of the art } \\
\text { technology for } \\
\text { more systematic } \\
\text { and efficient } \\
\text { towards zakat } \\
\text { collection and } \\
\text { distribution. }\end{array}$ & $\begin{array}{l}\text { The need for } \\
\text { strategic } \\
\text { marketing } \\
\text { planning and } \\
\text { activities are } \\
\text { required to give } \\
\text { awareness on } \\
\text { zakat to the zakat } \\
\text { payee and } \\
\text { recipient. }\end{array}$ & $\begin{array}{l}\text { Customer expects } \\
\text { to get aid } \\
\text { immediately and } \\
\text { periodically. }\end{array}$ \\
\hline $\begin{array}{l}\text { The needs for } \\
\text { demographic } \\
\text { studies to know } \\
\text { the number of } \\
\text { zakat payee and } \\
\text { recipients in the } \\
\text { state. }\end{array}$ & $\begin{array}{l}\text { Adhere to certain } \\
\text { best practices and } \\
\text { unable to } \\
\text { synergize the } \\
\text { current process to } \\
\text { a new } \\
\text { contemporary } \\
\text { paradigm in } \\
\text { technology and } \\
\text { process. }\end{array}$ & $\begin{array}{l}\text { Customer prefers } \\
\text { to have efficient } \\
\text { process of } \\
\text { collection with } \\
\text { acknowledgement } \\
\text { of distribution. }\end{array}$ \\
\hline
\end{tabular}

Table 4: Barriers to the implementation of CRM Zakat system

\begin{tabular}{|l|l|}
\hline \multicolumn{3}{|c|}{ CRM Zakat Implementation Barriers } \\
\hline $\begin{array}{l}\text { Negative perception from the } \\
\text { top management that the } \\
\text { system is complex and } \\
\text { difficult to be implemented. }\end{array}$ & $\begin{array}{l}\text { Lack of IT infrastructure for } \\
\text { sub urban area eg. No } \\
\text { internet accsess/zakat payee } \\
\text { prefer manual process. }\end{array}$ \\
\hline $\begin{array}{l}\text { Resource constraint in terms } \\
\text { of obtaining expert and } \\
\text { experience staff to manage } \\
\text { the system. }\end{array}$ & $\begin{array}{l}\text { Negative Zakat payer } \\
\text { perception on distribution. }\end{array}$ \\
\hline $\begin{array}{l}\text { The cost of implementation } \\
\text { is expensive. }\end{array}$ & $\begin{array}{l}\text { Sceptical on online } \\
\text { technology such as lack of } \\
\text { security }\end{array}$ \\
\hline $\begin{array}{l}\text { Refer to just a few best } \\
\text { practices which causing to } \\
\text { reluctant to change to a new } \\
\text { idea. }\end{array}$ & $\begin{array}{l}\text { Technology literacy gap } \\
\text { among the payer and } \\
\text { recipient. }\end{array}$ \\
\hline
\end{tabular}

The perceptions and barriers show that a proper CRM system is required. Therefore, it is proposed that an integrated systems (Smart Zakat System) is implemented in the Zakat institution. The system basically involves the entire operations to include aspects of Zakat operational (Collection and Distribution), financial, human resource management and procurement systems. Efficient, systematic and high integrity of Zakat CRM system will result in high customer satisfaction which produces a higher productivity of collection and distribution. This will make Zakat institution become strategically more productive economic institution that can benefit to the Muslim community in the state. It is hoped that this research contribute to the improvement of quality of service for the Zakat institution. The future research can be done to determine the CSF for successful implementation of Zakat CRM system.

\section{REFERENCES}

[1] A.W. Norazlina and A.R. Abdul Rahim. A framework to analyze the efficiency and governance of zakat institutions. Journal of Islamic Accounting and Business Research, Vol. 2 Iss: 1, pp.43 - 62, 2011.

[2] A.S. Al-Mudimigh, Z. Ullah and F. Saleem. Data Mining Strategies and Techniques for CRM Systems. IEEE International Conference on System of Systems Engineering (IEEESOSE), pp.1-5, 2009.

[3] A.S. Al-Mudimigh, F. Saleem, Z. Ullah and F.N. AlAboud. Implementation of Data Mining Engine on CRM - Improve Customer Satisfaction, Information and Communication Technologies, 2009. ICICT '09. International Conference on , page 193 - $197,15-16$ Aug. 2009.

[4] A.Ab. Rahman, M.H. Alias and S.M. Najib. Zakat Institution in Malaysia: Problems and Issues.AT | JUNE 2012 | VOL 2 ISSUE 1 | 35. ISSN: 2232-0474 | E-ISSN : 2232-0482, 2012. www.gjat.my

[5] L.H. Bibiano, J.M. Marco-Simo and J.A. Pastor. An initial approach for Improving CRM systems implementation projects, Information Systems and Technologies (CISTI), 2014 9th Iberian Conference on, pg IEEE, 1 - 6 , 18-21, 2014.

[6] C. Bull. Strategic Issues in Customer Relationship Management (CRM) Implementation. Business Process Management Journal, Vol. 9, No 5, 2003.

[7] F.A.A. Nadzri, R.A. Rahman and N. Omar. Zakat and Poverty Alleviation: Roles of Zakat Institutions in Malaysia. International Journal of Arts and Commerce, Vol. 1 No. 7, 2012.

[8] H. Harun, N. Nordin, and A. Hussain. Ontology of Zakat Management System, Proceedings of Knowledge Management International Conference (Kmice), Universiti Utara Malaysia, 2008.

[9] I. Corner and M. Hinton. Customer relationship management systems: Implementation risks and relationship dynamics. Qualitative Market Research: An International Journal Volume 5. Number 4. pp. 239-251, 2002.

[10] M. Lubis, N. I. Yaacob, Y. Omar and A.A. Dahlan. Enhancement of Zakat distribution management system: case study in Malaysia. In: Collaboration, communities, well-being and information system. IIUM Press, Kuala Lumpur, pp. 67-77, 2011. ISBN 9789674181024.

[11] S.F. King and T.F. Burgess. Understanding success and failure in customer relationship management, Industrial Marketing Management 37, pp.421-431, 2008.

[12] Y. Qardhawi. Fiqh Al Zakah. A Comparative Study of Zakah, Regulations and Philosophy in the Light of Quran and Sunnah. Vol. 1, Scientific Publishing Centre, King 
Abdul Aziz University, Jeddah (translated by M. Kahf), 2000.

[13] S. Ahmad, H. Wahid, and A. Mohamad. Penswastaan institusi Zakat and kesannya terhadap pembayaran secara formal di Malaysia, International Journal of Management Studies, Vol. 13, No. 2, pp. 175-196, 2006.

[14] W. Tie. Implementing CRM in SMEs: An Exploratory Study on the Viability of Using the ASP Model. Thesis in Accounting, Swedish School of Economics and Business Administration, 2003.

[15] H. Wahid, R.A. Kader and S. Ahmad. Localization of Zakat Distribution And The Role of Mosque: Perceptions of Amil And Zakat Recipients In Malaysia. In proceeding of the 13th Malaysia Indonesia Conference on Economics, Management and Accounting (MIICEMA) 2012. 